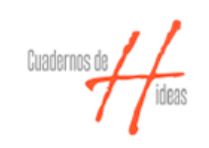

Cuadernos de $\mathrm{H}$ ideas

ISSN: 2313-9048

cuadernosdehideas@perio.unlp.edu.ar

Universidad Nacional de La Plata

Argentina

\title{
Ernesto Meccia. El tiempo no para: los últimos homosexuales cuentan la historia. Santa Fe, Ediciones UNL; Ciudad Autónoma de Buenos Aires, Eudeba, 2017, 556 páginas
}

\author{
Vespucci, Guido \\ Ernesto Meccia. El tiempo no para: los últimos homosexuales cuentan la historia. Santa Fe, Ediciones UNL; \\ Ciudad Autónoma de Buenos Aires, Eudeba, 2017, 556 páginas \\ Cuadernos de H ideas, vol. 12, núm. 12, 2018 \\ Universidad Nacional de La Plata, Argentina \\ DOI: https://doi.org/10.24215/23139048e018
}

Esta obra está bajo una Licencia Creative Commons Atribución-NoComercial-SinDerivar 4.0 Internacional. 
Reseñas bibliográficas

\title{
Ernesto Meccia. El tiempo no para: los últimos homosexuales cuentan la historia. Santa Fe, Ediciones UNL; Ciudad Autónoma de Buenos Aires, Eudeba, 2017, 556 páginas
}

\author{
Guido Vespucci guivespucci@yahoo.com.ar \\ Universidad Nacional de Mar del Plata, Argentina
}

\begin{abstract}
Meccia Ernesto. Ernesto Meccia. El tiempo no para: los últimos homosexuales cuentan la historia. Santa Fe, Ediciones UNL; Ciudad Autónoma de Buenos Aires, Eudeba, 2017, 556 páginas. 2017. Argentina. Ediciones UNL; Eudeba. 556pp.. 9789877490428
\end{abstract}

Cuadernos de $\mathrm{H}$ ideas, vol. 12, núm. 12, 2018

Universidad Nacional de La Plata, Argentina

Recepción: 15 Noviembre 2018 Aprobación: 17 Diciembre 2018

DOI: https://

doi.org/10.24215/23139048e 018

CC BY-NC-ND
En El tiempo no para... el sociólogo Ernesto Meccia se propone analizar las narrativas de varones homosexuales adultos y adultos mayores sobre la transformación de la homosexualidad en la ciudad de Buenos Aires y sus alrededores, acaecidas desde la reapertura democrática de 1983 hasta la actualidad. Así, el autor vuelve a recuperar el interés por conectar en una reflexión sociológica el cambio social con el cambio en las subjetividades, en una evidente continuidad con Los últimos homosexuales: sociología de la homosexualidad y la gaycidad(1) que surgió por la detección de un malestar que sentían estas personas a raíz de la velocidad con que ocurrían tales cambios, y que llevó al autor a proponer allí una clasificación histórica y macro-sociológica basada en tres períodos (homosexual, pregay y gay), alimentada en buena medida -aunque no exclusivamente- por la voz de esos actores. Aquí, esta periodización vuelve a retomarse con ligeros ajustes taxonómicos, pero la apuesta por lo micro-sociológico y las subjetividades aparece redoblada y será sin dudas el núcleo de los hallazgos y rendimiento de este libro a una pregunta de investigación sumamente original.

La primera parte del libro está destinada entonces a repasar aquella caracterización objetiva o macrosociológica de los tres períodos: homosexual, pre post-homosexual y post-homosexual. Dado que este encuadre será retomado en la segunda parte, daremos sucintamente algunas pistas. El primero, que llega hasta mediados de los 80 , coincide con los tiempos del silencio de una colectividad sufriente. Allí los homosexuales compartieron indelebles experiencias provocadas por la persecución policial y la estigmatización social, llevando a la formación 
de enclaves urbanos para poder desplegar prácticas homoeróticas de manera clandestina y secreta. En ese contexto proliferaron relaciones desjerarquizadas y fraternales, mediadas por códigos de igualitarismo y solidaridad que fueron imprescindibles para sostenerse en un régimen homofóbico y para vincularse ante la ausencia de un discurso propio con el cual autopercibirse. Durante el segundo período, que abarca la década del 90, comienza a advertirse la re-codificación de la eticidad del sufrimiento por la de un discurso de la no discriminación por orientación sexual, traccionado en buena medida por las nuevas organizaciones de reivindicación homosexual y gay. Este primer discurso propio invita a la visibilización de la homosexualidad, a un comingout colectivo, cuya máxima expresión son las marchas del orgullo gay. Sin embargo, esto no implica una ruptura radical con el régimen homosexual, ya que el lenguaje de la discriminación se asienta en una identificación con la experiencia del sufrimiento homosexual, así como con la promesa del destape y la liberación. El tercer período se inicia aproximadamente con el nuevo milenio, con una sinergia de procesos sociales, culturales y políticos de carácter positivo para con el reconocimiento de la homosexualidad. Desde el plano político, el nuevo entramado de leyes como la unión civil, el matrimonio igualitario, la identidad de género, hablan por sí solos de ese signo favorable en la atribución de derechos. Complementariamente, las políticas de visibilización fueron acompañadas por dinámicas socioculturales basadas en mecanismos de desenclave territorial, relacional y representacional. Es decir, espacios de sociabilidad, formas de relacionamiento y circulación de imágenes donde conviven gays y no gays, provocando a la postre efectos desdiferenciadores entre los universos simbólicos hetero y homosexual.

Consecutivamente, en la segunda parte el desafío del autor ya no es solo explicar macrosociológicamente este proceso de cambio del régimen de la homosexualidad al de la gaycidad, sino comprender y ordenar una vasta y variada producción de subjetividades (cómo los actores narran, y por ende valoran, significan y re-figuran, tal proceso de cambio) basada en una muestra de 31 entrevistas en profundidad que supusieron cerca de 70 encuentros cara a cara con los testimoniantes. Así, en esta sección nos encontramos con un texto polifónico sustentado en, como dice el autor, una "investigación cooperativa" entre la voz de los legos y la del sociólogo, donde conviven diferentes formas de conocer, una de las cuales es el conocimiento sociológico. Asimismo, "su voz sociológica" no solo está en su diálogo con los entrevistados, sino además en un trabajo de interpretación y ordenamiento de esa vasta y variada producción de narrativas mediante profusas y fértiles clasificaciones y elaboración de categorías analíticas. En efecto, para cada período planteado (homosexual, pre-post-homosexual, post-homosexual), el autor nos propone no una teoría o interpretación unificada, sino diversas clasificaciones y categorías que ordenan y acompañan los relatos sobre dos ejes: teorías sobre la organización social y teorías sobre el yo, es decir, qué dicen recordar los actores sobre lo social y sobre sí mismos, y cómo lo significan desde su presente. A su vez, otra herramienta fundamental para interpretar y 
ordenar estos relatos, supone la detección de fuerzas o potencias narrativas que transportan personajes, no necesariamente coincidentes con personas reales, sino personajes narrativos que tienen agencia, y que pendulan de lo concreto a lo más abstracto: personajes-personas; personajes-roles y personajes-fuerza.

De este modo, para el período homosexual, las teorías sobre la organización social están atravesadas por narrativas como las de asechanza, en las que se detectan personajes-fuerza como "la represión" y "las razzias", fuerzas ejercidas por personajes-rol como "la policía", y donde los homosexuales se autoperciben como personajes-personas pasivas -objetos de violencia y sometidos a una sensación permanente de riesgos- sin posibilidades de cambiar el estado de cosas. Sin embargo, la imagen de una "ciudad sitiada" también convive con narrativas de explotación territorial, donde los homosexuales se reapropian de ciertos espacios (estaciones de trenes y micros, cines, baños públicos o "teteras", entre otros) para desplegar prácticas homoeróticas y resistir la colonización heteronormativa del territorio. Las evocaciones a esos escenarios y a esas prácticas se enmarcan en narrativas de búsqueda comunitaria y hermenéutica, es decir, como intentos para poder reconocerse e identificarse como colectivo en un contexto histórico donde -salvo los incipientes alcances de organizaciones como Nuestro Mundo o el Frente de Liberación Homosexual en proveer un discurso para la cuestión homosexual- no hay un guión cultural propio.

Precisamente, en las teorías del yo para este período, Meccia registra relatos convergentes con esa organización social heteronormativa. Así, las narrativas de desconocimiento, desdoblamiento y de contra imágenes del yo, expresan sensaciones de extrañamiento, soledad y dificultades para reconocerse en un yo escindido y desgarrado, y son en buena medida efecto de ese régimen heterocentrado. Las alusiones de los entrevistados a sentirse monstruoso, triste y desdichado resultan, por cierto, pasajes altamente movilizantes de la obra.

Este encuadre asistirá a algunos cambios cuando los entrevistados pasen a referirse al período pre post-homosexual, coincidente con la etapa de recuperación democrática. Aquí, el trabajo de Meccia logra relevar una serie de narrativas significativas para contribuir a la comprensión de las percepciones relativas a los cambios y las continuidades respecto al período previo. Una de ellas, que habitualmente caracteriza la imagen que las investigaciones proveen para ese contexto, es la de visibilización. La misma evoca una disposición al coming-out colectivo que es motorizada por el trabajo de representación política de nuevos personajes-roles como la Comunidad Homosexual Argentina, Gays por los Derechos Civiles, entre otras asociaciones, y "emprendedores morales", como Carlos Jáuregui, que favorecen esa disposición en los personajes-personas homosexuales. Correlativamente, se evocan otros personajes-fuerza que colaboran en recrear aquel clima de "destape", tales como revistas, películas y demás bienes simbólicos referidos a la temática gay. A través de esos relatos, Meccia profundiza en una línea analítica original que ya estaba presente en Los últimos homosexuales... y que ahora viene a categorizar 
como narrativas anti-materialistas, las que consisten en personajes-fuerza como la globalización, el neoliberalismo, el consumismo, el marketing, desde donde se van delineando personajes-rol gays de carácter frívolos, estandarizados, despolitizados, de clase media, preocupados por su cuerpo y figura. Más consabido como tópico pero no por eso menos relevante, e incluso igualmente original en su abordaje y hallazgos, son las narrativas sobre el SIDA. Aquí el autor encuentra llamativa la exigua evocación a la epidemia, lo que no significaría estrictamente una ausencia en el imaginario de los entrevistados. Obligado a dilucidar tal exigüidad, su apuesta explicativa radica en comprender cómo opera la memoria cuando es narrada, en la línea que abrieron los trabajos de Michael Pollak (2). $\mathrm{Su}$ funcionamiento es selectivo, y frente a hechos inconmensurables como una guerra, la memoria puede silenciar, ocultar o desplazar. De igual modo, ante un hecho tan traumático como la epidemia del SIDA, los entrevistados parecen haber elegido no hablar del tema, o no saber cómo hablarlo, silenciando o reprimiendo sensaciones de profundo sufrimiento. En quienes sí lograron tematizar el SIDA emergen evocaciones que van en la dirección detectada por Mario Pecheny (3), esto es, concebir la epidemia como un vector de reconocimiento de derechos por la forzosa visibilización de la homosexualidad que trajo aparejada. Así se comprende que pueda ser recordada e investida por un sentido de oportunidad para "sacarse todos los closets de encima".

Complementariamente, las teorías del yo en este período están basadas en lo que Meccia denomina narrativas de flexibilización. Las mismas están nutridas por imágenes relativas a la deflación de temores, los permisos auto-otorgados para transitar lugares, experimentar relaciones homoeróticas y homoafectivas con menos culpa, "destrabarse" y adjudicarse $-\mathrm{y}$ esto es sumamente importante en la narración de esta historia- una primera visión de sí mismos, luego de haber transitado la incertidumbre, el extrañamiento y el desdoblamiento del yo. En definitiva, como dicen los entrevistados, se está mejor y se puede mejorar más, aunque sin garantías, puesto que las fuerzas homofóbicas externas $\mathrm{o}$ internas pueden aflorar en cualquier momento, y en el período posthomosexual se verá que pueden nunca desaparecer.

En efecto, este período es evocado bajo profusas tensiones y percepción de contradicciones. Aquí las teorías del yo están tensionadas por narrativas de reparación, cuyo emblema más significativo es la ley de matrimonio igualitario, y por narrativas de resabios del régimen social heteronormativo. Es decir, los actores aluden sentirse mejor, quizás como nunca antes, pero a la vez sintiendo el peso del infausto pasado. Consecutivamente, sus ideas acerca de la organización social están envueltas en variadas narrativas que recrean la complejidad de este período, sus importantes líneas de transformación, sus permanencias y puntos de fricción. Así, conviven narrativas de mejoramiento con narrativas de asignaturas pendientes, narrativas sobre la lógica comercial de la gaycidad con narrativas de perplejidad, perplejidad que se sintetiza en expresiones del estilo a "cómo puede ser que pase esto en este contexto". Esto pone en evidencia que "solo con los derechos ganados 
no alcanza", mientras su acceso sea obstaculizado o empañado por los peores valores y dinámicas de sociabilidad de la gaycidad convertida en "carcasa marketinera fascista", donde se producen constantemente patrones de diferencia como desigualdad ("discriminación") basados en criterios exclusivos y excluyentes de clase, edad y racialización. En consonancia -y este constituye un aporte central del autor, que ya estaba elaborado conceptualmente en Los últimos homosexuales... y que aquí logra registrar con densidad y matices- los actores perciben estas tensiones mediante narrativas de diferenciación y des-diferenciación. Esta última evoca un relajamiento en los marco etiquetamientos homosexualidad/ heterosexualidad, producto de procesos históricos de desenclave espacial, relacional y representacional. Así, emergen las imágenes de que en definitiva "la homosexualidad no es nada", que "cualquiera puede serlo", o que "la apertura mental" de estos tiempos hace que "la gente ya no te pregunte" si sos homosexual o gay. Sin embargo, y esto es lo que parece chocar, desencajar e indignar a muchos de los entrevistados, el régimen de la gaycidad transformó este colectivo social sufriente con sus códigos de igualitarismo y solidaridad conformados por haber compartido la experiencia cotidiana del estigma y la clandestinidad, así como las promesas de liberación que hicieron fuerte eclosión en la época del destape- en una categoría social en la que ya no se comparten valores comunes ni un sentido de membresía sino, a lo sumo, la coincidencia de atributos sociales que son exclusivos o están desigualmente distribuidos. "Los gays de ahora ya no tienen códigos", "es gente fría", "menos respetuosa $y$ solidaria", no conforman "verdaderas amistades" o relaciones sino que actúan "por interés", son expresiones que confluyen finalmente en que los gays de ahora "ya no son como nosotros", los últimos homosexuales.

Luego de La cuestión gay(4) y Los últimos homosexuales, con El tiempo no para, Ernesto Meccia continúa realizando aportes centrales al campo de estudios sobre homosexualidades en Argentina, brindando orientaciones conceptuales fértiles para incorporar, compartiendo hallazgos empíricos susceptibles de comparar y abriendo líneas de indagación originales pasibles de continuar explorando. Porque si bien este libro nos deja una mezcla de sabores y sinsabores gracias a la narración de esta historia -habitada tanto por tormentosos pasados y promesas utópicas como por reparaciones, perplejidades y negatividades percibidas desde el presente- también nos invita a pensar sobre el futuro a partir de todo lo que queda por hacer para mejorar la cuestión de la diversidad sexual.

\section{Notas}

(1) Meccia, Ernesto. Los últimos homosexuales: sociología de la homosexualidad y la gaycidad. Buenos Aires, Gran Aldea Editores, 2011.

(2) Pollak, Michael. Memoria, olvido, silencio. La producción social de identidades frente a situaciones limite, La Plata, Ediciones Al Margen, 2006.

(3) Pecheny, Mario. "La salud como vector del reconocimiento de derechos humanos: la epidemia del sida y el reconocimiento de los derechos de las 
Guido Vespucci. Ernesto Meccia. El tiempo no para: los últimos homosexuales cuentan la historia. Santa Fe, Ediciones UNL; Ciudad Autónoma de...

minorías sexuales”, en Domínguez Mon, Ana et al.: La salud en crisis: una mirada desde las ciencias sociales. Buenos Aires, Dunken, 2000, pp. 199-215.

(4) Meccia, Ernesto. La cuestión gay: un enfoque sociológico. Buenos Aires, Gran Aldea Editores, 2006.

\section{Enlace alternativo}

http://perio.unlp.edu.ar/ojs/index.php/cps/index (html) 